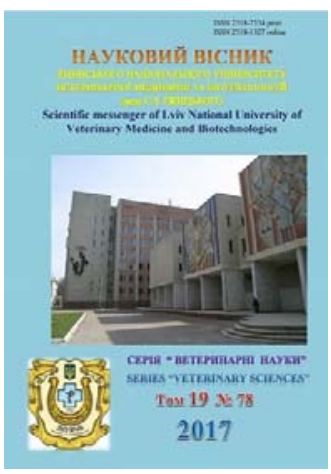

Науковий вісник Львівського національного університету ветеринарної медицини та біотехнологій імені С.З. Гжицького

Scientific Messenger of Lviv National University of Veterinary Medicine and Biotechnologies

doi:10.15421/nvlvet7812

ISSN 2518-7554 print

ISSN 2518-1327 online

$\underline{\text { http://nvlvet.com.ua/ }}$

УДК $631.57: 664.126(4778)$

\title{
Ветеринарно-санітарна оцінка якості та безпеки харчових продуктів у Житомирському регіоні
}

\author{
В.А. Котелевич \\ valya.kotelevich@ukr.net \\ Житомирський національний агроекологічний університет, \\ вул. Корольова, 39, м. Житомир, 10025, Україна
}

\begin{abstract}
Наведено результати ветеринарно-санітарної експертизи харчових продуктів за даними Житомирської регіональної державної лабораторії ветеринарної медицини (2014-2015 рр.) і державних лабораторій ветеринарно-санітарної експертизи господарчих ринків м. Житомира та Житомирської області. Основною причиною вибраковки субпродуктів за 2014 2015 рр. були інвазійні захворювання, в тому числі 658 (3,45\%) випадків фасциільозу при дослідженні продуктів забою ВРХ, 5033 - ехінококозу (3,59\%) i 413 (0,29\%) - метастронгільозу у свиней. За показниками якості та безпеки (вміст токсичних елементів, пестицидів, мікотоксинів, антибіотиків) напівкопчені та варені ковбаси вищого, 1 і 2 татунку відповідали нормативним вимогам. За санітарними показниками у 4,4\% зразків иии м'ясопродуктів були виділені бактерії групи кишковоі палички, у 11,1\% - мезофільні аеробні та факультативно-анаеробні мікроорганізми. Вони за відповідних умов можуть викликати харчові токсикоінфекиї, тому ковбасні вироби були направлені на знешкодження шляхом проварювання і переведені на нижчі сорти. Проведені бактеріологічні дослідження зразків м'яса щзодо наявності ентеробактерій, МАФАнМ (мезофільні аеробні та факультативно анаеробні мікроорганізми) і бактерій роду Salmопеlla одразу після забою показали, що кількість мікроорганізмів на поверхні туш становила: роду Enterobacteriaceae $28,5 \pm 1,1 \mathrm{KУO} \times 10^{5} / \mathrm{cm}^{2}$, мезофільних

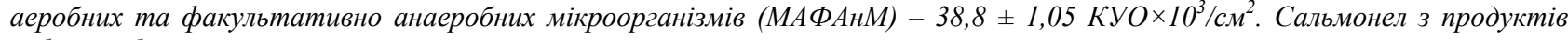
забою не було виявлено.

Гарантом безпеки молочної продукиії в Україні залитається система моніторингу санітарно-небезпечних збудників та залишкових кількостей токсичних речовин. Для усунення ризику небезпек споживача молочної продукиї необхідно удосконалювати систему контролю сировини, яку використовують для виготовлення продуктів, за показниками безпеки на всіх етапах виробництв. Вважаємо за доцільне звернути увагу фахівиів ветеринарної медицини на ветеринарно-санітарний стан молока і молочних продуктів, посилення контролю в державних лабораторіях ветсанекспертизи господарчих ринків на виявлення антибіотиків та при подвірному забої тварин щьодо недопущення в реалізачію недоброякісних продуктів, поліпшення санітарного стану умов зберігання та реалізації тваринницької продукиії, профілактику інвазійних та незаразних хвороб у великої рогатої худоби і свиней.

Ключові слова: якість, безпека, харчові продукти, токсичні елементи, пестициди, мікотоксини, антибіотики, МАФАнМ, Salmonella, ентеробактерії, вибраковка субпродуктів.
\end{abstract}

\section{Ветеринарно-санитарная оценка качества и безопасности пищевых продуктов в Житомирском регионе}

\author{
В.А. Котелевич \\ valya.kotelevich@ukr.net
}

Житомирский национальный агроэкологический университет, ул. Королева, 39, г. Житомир, 10025, Украина

\section{Citation:}

Kotelevich, V.A. (2017). Veterinary and sanitary assessment of food quality and safety in Zhytomyr region. Scientific Messenger LNUVMB, 19(78), 58-61. 
Приведенные результаты ветеринарно-санитарной экспертизы пищевых продуктов за данными Житомирской областной государственной лаборатории ветеринарной медицины (2014-2015 г.) и государственных лабораторий ветеринарносанитарной экспертизы хозяйственных рынков г. Житомира и Житомирской области. Основной причиной выбраковки субпродуктов по 2014-2015 г2. были инвазионные заболевания, в том числе 658 (3,45\%) случаев фасииолеза при исследовании продуктов убоя КРС, 5033 - эхинококкоза (3,59\%) и 413 (0,29\%) - метастронгилеза у свиней. По показателям качества и безопасности (содержание токсичных элементов, пестицидов, микотоксинов, антибиотиков) полукопченые и вареные колбасы высшего, 1 и 2 сорта соответствовали нормативным требованиям. По санитарным показателям в 4,4\% образиов этих мясопродуктов были выделены бактерии группы кишечной палочки, в 11,1\%-мезофильные аэробные и факультативно-анаэробные микроорганизмы. Они при соответствующих условиях могут вызвать пищевые токсикоинфекиии, поэтому колбасные изделия были направлены на обезвреживание путем проваривания и переведены на низшие сорта. Проведенные бактериологические исследования образиов мяса на наличие энтеробактерий, МАФАнМ (мезофильные аэробные и факультативно анаэробные микроорганизмы) и бактерий рода Salmonella сразу после забоя показали, что количество микроорганизмов на поверхности туш составила: рода Enterobacteriaceae 28,5 $\pm 1,1 \mathrm{KOE} \times 10^{5} \mathrm{~cm}^{2}$, мезофильных аэробных и факультативно анаэробных микроорганизмов (МАФАнМ) - 38,8 $\pm 1,05 \mathrm{KOE} \times 10^{3} \mathrm{~cm}^{2}$. Сальмонелл из продуктов забоя не было обнаружено.

Гарантом безопасности молочной продукиии в Украине остается система мониторинга санитарно опасных возбудителей и остаточных количеств токсичных веществ. Для устранения риска опасности для потребителя молочной продукичи необходимо совершенствовать систему контроля сырья, используемого для изготовления продуктов по показателям безопасности на всех этапах производства. Считаем иелесообразным обратить внимание специалистов ветеринарной медииины на ветеринарно-санитарное состояние молочных продуктов, усиление контроля в государственных лабораториях ветсанэкспертизы хозяйственных рынков на наличие антибиотиков и при подворном убое животных по недопущению в реализацию недоброкачественных продуктов, улучшение санитарного состояния условий хранения и реализации животноводческой продукиии, профилактику инвазионных и незаразных болезней у крупного рогатого скота и свиней.

Ключевые слова: качество, безопасность, пищевые продукты, токсичные элементы, пестициды, микотоксины, антибиотики, МАФАнМ, Salmonella, энтеробактерии, выбраковка субпродуктов.

\title{
Veterinary and sanitary assessment of food quality and safety in Zhytomyr region
}

\author{
V.A. Kotelevich \\ valya.kotelevich@ukr.net
}

\begin{abstract}
Zhytomyr National Agroecological University,
\end{abstract}
Korolova Str., 39, Zhytomyr, 10025, Ukraine

The results of Veterinary Expertise of food according to Zhytomyr Regional State Veterinary Laboratory (2014-2015rr.) And state laboratories Veterinary Expertise of household markets. Zhytomyr and Zhytomyr region. The main reason for culling offal 2014-2015 gg. Were invasive disease, including 658 (3.45\%) patients in the study Fasciolosis products of slaughter cattle, 5033 echinococcosis (3.59\%) and $413(0.29 \%)$ - Metastrongillosis in pigs. In terms of safety and quality (content of toxic elements, pesticides, mycotoxins, antibiotics) sausage and cooked sausage highest, grade 1 and 2 met the regulatory requirements. For sanitary indicators in $4.4 \%$ of samples of meat products were isolated Escherichia coli in $11.1 \%$ - mesophilic aerobic and facultative anaerobic microorganisms. They can, under appropriate conditions, cause food poisoning, so sausage wares have been directed to disinfection by evaporation and translated into lower grades. We conducted bacteriological tests of meat samples availability of enterobacteria, MAFAnM (mesophilic aerobic and facultative anaerobic bacteria) and bacteria of the genus Salmonella immediately after slaughter showed that the number of microorganisms on the surface of the ink was: kind of Enterobacteriaceae 28,5 $\pm 1,1 \times 10^{5}$ $\mathrm{CFU} / \mathrm{cm}^{2}$, mesophilic aerobic and optionally anaerobic microorganisms (MAPANM) $-38.8 \pm 1.05 \mathrm{CFU} \times 10^{3} / \mathrm{cm}^{2}$. Salmonella from carcass was not detected.

The dairy product safety guarantor in Ukraine remains a system for monitoring sanitary hazards and residual amounts of toxic substances. In order to eliminate the risk of dangers to the consumer of dairy products, it is necessary to improve the control system of raw materials used for manufacturing products, according to safety indicators at all stages of production. Therefore, we consider it appropriate to draw the attention of specialists of veterinary medicine in the veterinary and sanitary conditions of milk and dairy products, gain control in government laboratories vetsanekspertizy household markets using antibiotics and in slaughtered animals to prevent a realization of substandard products, improve the sanitary condition of the storage and implementation of animal Products, prevention of invasive and non-contagious diseases in cattle and pigs.

Key words: quality, safety, food products, toxic elements, pesticides, mycotoxins, antibiotics, MAФAнM, Salmonella, enterobacteria, discarding of byproducts.

\section{Вступ}

Якість та безпека продукції є одним 3 найважливіших і пріоритетних завдань держави. На сьогодні в усьому світі стали суттєво жорсткішими вимоги, що висуваються споживачем до якості продукції. У сучасних умовах жорсткої конкурентної боротьби за ринки збуту продукції підприємства розвинутих країн все ширше застосовують ефективний інструмент забезпечення успіху - системи якості, які відповідають визнаним міжнародним вимогам, що містяться у Міжнародних та Свропейських стандартах з якості та сертифікаціï (Zakon Ukrajiny, 1991; Zakon Ukrajiny, 2005; Trush et al., 2009). Виробництво та реалізація безпечних харчових продуктів $є$ важливою передумовою збереження здоров'я населення країни. Забезпе- 
ченість екологічно-чистими продуктами харчування була і залишається загальнодержавною проблемою України, що потребує першочергового вирішення.

У зв'язку з переходом України на ринкові відносини і пов'язані з ними перебудовні процеси в сільському господарстві почали різко з'являтися численні фактори, котрі мають негативний вплив на якість продуктів тваринництва, особливо тих, що безпосередньо виробляються в самих господарствах. Розширення сфери переробки тварин в умовах господарств знижує ефективність ветеринарно-санітарного контролю за переробкою сировини тваринного походження і сприяє порушенню санітарно-гігієнічних умов технології забою тварин, збереженню м'яса, його переробки і транспортування, а також можливе обсіменіння мікрофлорою продуктів забою тварин, що зможе призвести до захворювання людей.

Метою наших досліджень було вивчити екологічні аспекти якості та безпеки харчових продуктів у Житомирському регіоні. Для вирішення вищезазначеної мети перед нами були поставлені такі завдання:

- провести аналіз звітної документації Житомирської РДЛВМ та державної лабораторії ветсанекспертизи господарчого ринку м. Житомир за 20142015 pp;

- провести порівняльний аналіз якості та безпеки м'яса, м'ясопродуктів, молока та молокопродуктів, що надходили на дослідження в ЖРДЛВМ протягом 2014-2015 років.

\section{Матеріал і методи досліджень}

Матеріалом наших досліджень була звітна документація Житомирської регіональної державної лабораторії ветеринарної медицини (ЖРДЛВМ) за 2014-2015 рр., державних лабораторій ВСЕ господарчих ринків м. Житомира і Житомирської області; зразки м'ясних та молочних продуктів. Наші дослідження включали: органолептичні, фізико-хімічні та контроль за показниками безпеки (токсичні елементи, антибіотики, мікробіологічні показники) за загальноприйнятими методами.

\section{Результати та їх обговорення}

Аналіз звітної документації державних лабораторій ветсанекспертизи господарчих ринків Житомирської області за 2014-2015 роки свідчить, що провідну ланку при вибраковці продуктів забою займають інвазійні захворювання, а саме: фасціольоз великої рогатої худоби, метастронгільоз та ехінококоз свиней. Певна частина продукції вибраковувалась через незадовільність органолептичних показників: неспецифічний запах, забруднення та крововиливи. За даний період спеціалістами державних лабораторій ветеринарно-санітарної експертизи оглянуто i проведено експертиз 444188, проведено лабораторних досліджень 1362304; направлені на утилізацію 35 кг яловичини, 270 кг свинини і 58 кг м'яса кролів, нутрії та дичини. При цьому від великої рогатої худоби та сви- ней було недоотримано 1,903 т і 8,272 т субпродуктів відповідно.

Крім м'яса та субпродуктів, недопущено до реалізації такі харчові продукти:

- риба та рибопродукти - всього 274 випадки, вагою 6,587 т, знезаражено 3,373 т (за результатами біохімічних досліджень, порушення термінів реалізації, відсутні документи, повторна дифростація), утилізовано 3,214 т (за результатами біохімічних досліджень, порушення термінів реалізації, відсутні документи);

- яйця - всього 96 випадків 103,866 тис. штук $(29,95$ т), у т. ч.: знезаражено 103,243 тис. шт. (з причин побитостей, механічної забрудненості), утилізовано 0,886 тис. шт. (з причин порушення термінів та умов зберігання, за результатами овоскопії);

- $\quad$ молоко та молокопродукти - всього 4893 випадків, вагою 32,427 т, знезаражено 10,521 т (з причин порушення термінів реалізації, механічної забрудненості, фальсифікації, незадовільних органолептичних показниках, жир та кислотність не відповідали нормі), утилізовано 21,9 т (з причин порушення термінів реалізації, механічної забрудненості, маститів, органолептики, жиру, кислотність не відповідає нормі, перевищення за ДР-2006) (Kotelevych and Makarenko, 2016).

340 досліджуваних зразків напівкопчених ковбасних виробів 12,5\% не відповідали за масовою часткою вологи, 2,5\% - за масовою часткою солі та крохмалю.

При бактеріологічному дослідженні ковбасних виробів встановлено, що 10\% напівкопчених ковбасних виробів не відповідали вимогам за вмістом бактерій групи кишкової палички (БГКП), 12\% варених ковбасних виробів - за вмістом КМАФАнМ, КУО та 12\%за БГКП. 3 усіх досліджуваних ковбасних виробів $11,1 \%$ не відповідали вимогам за вмістом КМАФАнМ, КУО та 4,4\% - за вмістом бактерій групи кишкової палички (Kotelevych et al., 2015).

За показниками якості та безпеки (вміст токсичних елементів, пестицидів, мікотоксинів, антибіотиків) напівкопчені та варені ковбаси вищого, 1 і 2 гатунку відповідали нормативним вимогам.

Отже, 11,1\% з усіх досліджуваних (90 проб) ковбасних виробів не відповідали вимогам за масовою часткою вологи, 2,2\% - за масовою часткою солі; $2,2 \%$ за масовою часткою нітриту натрію; 8,9\% - за масовою часткою крохмалю. За санітарними показниками у 4,4\% зразків цих м'ясопродуктів були виділені бактерії групи кишкової палички, у 11,1\% - мезофільні аеробні та факультативно-аеробні мікроорганізми. Вони за відповідних умов можуть викликати харчові токсикоінфекції, тому ковбасні вироби були направлені на знешкодження шляхом проварювання i переведені на нижчі сорти (Posudin, 2005).

При визначенні відповідності проб молока фізикохімічним показникам встановлено, що 3 25 досліджуваних зразків молока 1 проба (4,0\%) не відповідала вимогам за масовою часткою жиру, за кислотністю та наявністю інгібуючих речовин.

За вмістом соматичних клітин 3 досліджених 25 зразків - 3 проби (12\%) не відповідали норматив- 
ним вимогам. У досліджених зразках молока залишкових кількостей антибіотиків не встановлено. Таким чином, за результатами імуноферментних досліджень на вміст антибіотиків молоко $є$ безпечним для використання.

За результатами проведених досліджень, S. aureus, БГКП (колі-форми), патогенні мікроорганізми, в тому числі сальмонели, не було виявлено у жодному зразку молока та молокопродуктів. Кількість МАФАнМ, КУО в 1 г у досліджуваних пробах перебувала в межах $4,0 \cdot 10^{3}-4,5 \cdot 10^{3}$ КУО в 1 г (при допустимому рівні не більше $1 \cdot 10^{5}$ КУО в 1 г), тобто не перевищувала допустимих меж. Вміст дріжджів та грибів плісені у зразках молочної продукції не виділено (допустима концентрація - не більше 100 КУО в 1 г). За мікробіологічними показниками (КМАФАнМ; БГКП; St. aureus; патогенні мікроорганізми, у т. ч. сальмонели) усі досліджені зразки молока не перевищували допустимого рівня.

Проведені нами бактеріологічні дослідження зразків м'яса щодо наявності ентеробактерій, МАФАнМ (мезофільні аеробні та факультативно анаеробні мікроорганізми) і бактерій роду Salmonella одразу після забою показали, що кількість мікроорганізмів на поверхні туш становила: роду Enterobacteriaceae 28,5 \pm 1,1 КУО $\times 10^{5} / \mathrm{cm}^{2}$, мезофільних аеробних та факультативно анаеробних мікроорганізмів (МАФАнМ) $38,8 \pm 1,05 \mathrm{KУО} \times 10^{3} / \mathrm{cm}^{2}$. Сальмонел 3 туш не було виявлено.

\section{Висновки}

Державні лабораторії ветсанекспертизи господарчих ринків Житомирського регіону і Житомирська регіональна державна лабораторія ветеринарної медицини проводять велику роботу в плані недопущення до реалізації недоброякісної та шкідливої харчової продукції.

Встановлено, що основною причиною вибраковки субпродуктів за 2014-2015 рр. були інвазійні захворювання, в тому числі 658 (3,45\%) випадків фасціольозу при дослідженні продуктів забою ВРХ, 5033 ехінококозу (3,59\%) і 413 (0,29\%) - метастронгільозу у свиней.

За показниками якості та безпеки (вміст токсичних елементів, пестицидів, мікотоксинів, антибіотиків) напівкопчені та варені ковбаси вищого, 1 і 2 гатунку відповідали нормативним вимогам. За санітарними показниками у 4,4\% зразків цих м'ясопродуктів були виділені бактерії групи кишкової палички, у 11,1\% мезофільні аеробні та факультативно-анаеробні мікроорганізми, що за відповідних умов можуть викликати харчові токсикоінфекції.

Основою гарантування безпеки молочної продукції в Україні залишається система моніторингу санітарно небезпечних збудників та залишкових кількостей токсичних речовин. Для усунення ризику небезпек споживача молочної продукції необхідно удосконалювати систему контролю сировини, яку використовують для виготовлення продуктів, за показниками безпеки на всіх етапах виробництва.

Перспективи подальших досліджень будуть спрямовані на вивчення санітарної якості та біологічної цінності субпродуктів після зачистки 3 причин інвазійних захворювань.

\section{Бібліографічні посилання}

Trush, A.M., Jacenko, I.V., Deghtjarjov, M.O. (2009). Ekspres-dovidnyk $\mathrm{z}$ veterynarnoji ekspertyzy $\mathrm{V}$ pytannjakh ta vidpovidjakh. Kh. (in Ukrainian).

Zakon Ukrajiny (1991). Pro zakhyst prav spozhyvachiv. 1023-KhII vid 12 travnja 1991 r. zi zminamy (in Ukrainian).

Zakon Ukrajiny (2005). Pro bezpechnistj ta jakistj kharchovykh produktiv. 2809-IV vid 06 veresnja 2005 r. (in Ukrainian).

Kotelevych, V.A., Makarenko, V.O. (2016). Analiz mikrobiologhichnykh pokaznykiv u moloci ta molokoproduktakh za danymy ZhRDLVM. Materialy Vseukr. nauk.-prakt. internet-konf. «Suchasni aspekty likuvannja i profilaktyky khvorob tvaryn» (24-25 lystopada 2016 r.). Poltava, 96-98 (in Ukrainian).

Kotelevych, V.A., Zghozinsjka, O.A., Gholovko, O.V. (2015). Vetsanekspertyza i vetsanocinka kovbas TOV «Sumsjki m'jasni vyroby». Visnyk ZhNAEU. 1(49), 3, 128-130 (in Ukrainian).

Posudin, Ju.I. (2005). Metody nerujnivnoji ocinky jakosti ta bezpeky siljsjkoghospodarsjkykh i kharchovykh produktiv. Kyjiv (in Ukrainian).

Received 4.09.2017

Received in revised form 30.09.2017

Accepted 5.10.2017 